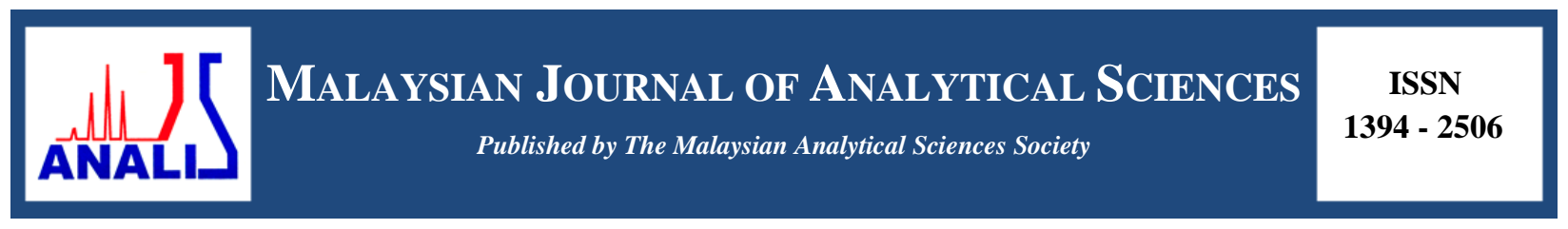

\title{
DETERMINATION OF OPTIMUM CONDITION OF LEUCINE CONTENT IN BEEF PROTEIN HYDROLYSATE USING RESPONSE SURFACE METHODOLOGY
}

\author{
(Penentuan Keadaan Optimum bagi Kandungan Leusina di dalam Protein Hidrolisat Daging \\ Menggunakan Kaedah Gerak Balas Permukaan)
}

\author{
Siti Roha Ab Mutalib, Zainal Samicho*, Noriham Abdullah \\ Programme of Food Science and Technology, \\ Faculty of Applied Sciences, \\ Universiti Teknologi MARA, 40450 Shah Alam, Selangor, Malaysia
}

*Corresponding author: zainal147@salam.uitm.edu.my

Received: 24 February 2015; Accepted: 27 October 2015

\begin{abstract}
The aim of this study is to determine the optimum condition of leucine content in beef hydrolysate. Beef hydrolysate was prepared by enzymatic hydrolysis using bromelain enzyme produced from pineapple peel. Parameter conditions such as concentration of bromelain, hydrolysis temperature and hydrolysis time were assessed to obtain the optimum leucine content of beef hydrolysate according to experimental design which was recommended by response surface methodology (RSM). Leucine content in beef hydrolysate was determined using AccQ.Tag amino acid analysis method using high performance liquid chromatography (HPLC). The condition of optimum leucine content was at bromelain concentration of $1.38 \%$, hydrolysis temperature of $42.5^{\circ} \mathrm{C}$ and hydrolysis time of 31.59 hours with the predicted leucine content of $26.57 \%$. The optimum condition was verified with the leucine value obtained was $26.25 \%$. Since there was no significant difference $(p>0.05)$ between the predicted and verified leucine values, thus it indicates that the predicted optimum condition by RSM can be accepted to predict the optimum leucine content in beef hydrolysate.
\end{abstract}

Keywords: leucine, enzymatic hydrolysis, bromelain, response surface methodology

\begin{abstract}
Abstrak
Matlamat kajian ini adalah untuk menentukan keadaan optimum kandungan leusina di dalam hidrolisat daging lembu. Hidrolisat daging lembu telah disediakan secara hidrolisis enzim menggunakan enzim bromelin yang dihasilkan daripada kulit nanas. Keadaan parameter seperti kepekatan bromelin, suhu hidrolisis dan masa hidrolisis telah dinilai untuk mendapatkan kandungan leusina yang optimum dari hidrolisat daging lembu mengikut reka bentuk eksperimen yang disyorkan oleh kaedah gerak balas permukaan (RSM). Kandungan leusina di dalam hidrolisat daging lembu telah ditentukan dengan menggunakan kaedah analisis AccQ.Tag asid amino menggunakan kromatografi cecair prestasi tinggi (HPLC). Keadaan optimum kandungan leusina didapati pada kepekatan bromelin $1.38 \%$, suhu hidrolisis $42.50{ }^{\circ} \mathrm{C}$ dan masa hidrolisis 31.59 jam dengan kandungan leusina yang diramalkan adalah $26.57 \%$. Keadaan optimum telah disahkan di mana nilai leusina diperolehi adalah $26.25 \%$. Oleh kerana tiada perbezaan yang signifikan ( $\mathrm{p}>0.05$ ) antara nilai leusina yang diramalkan dan disahkan, maka ia menunjukkan bahawa keadaan optimum yang diramalkan oleh RSM boleh diterima dan digunakan untuk meramalkan kandungan leusina yang optimum dalam hidrolisat daging lembu.
\end{abstract}

Kata kunci: leusina, hydrolisis enzim, bromelin, kaedah gerak balas permukaan 


\title{
Siti Roha et al: DETERMINATION OF OPTIMUM CONDITION OF LEUCINE CONTENT IN BEEF \\ PROTEIN HYDROLYSATE USING RESPONSE SURFACE METHODOLOGY
}

\begin{abstract}
Introduction
Beef consumption has decreased in the last decades due to negative health images [1]. Many studies deal with the opportunities of enhancing the beneficial fatty acids such as increasing the $n-3$ polyunsaturated fatty acids and conjugated linoleic acids (CLA) and reducing saturated fatty acids (SFA) in beef. In addition, limited knowledge is known about the alteration of other nutritional ingredients such as amino acid composition in beef $[2,3]$. Meat and meat products are good sources of protein for human consumption. These proteins are well balanced in amino acid and contain all essential amino acids that human cannot synthesize. However, certain people are advised not to consume beef due to health problems. According to Bjoern et al. [4] several essential amino acids such as leucine and phenylalanine or non-essential amino acids such as arginine and glutamine, have shown to directly stimulate insulin secretion from pancreatic beta-cells, resulting in beneficial therapeutic effects in patients with type 2 diabetes.
\end{abstract}

One of the methods for protein recovery from this meat protein is production of protein hydrolysate through enzymatic hydrolysis. It is widely employed to improve nutritional and functional properties of meat protein. In the effort of attempting to hydrolyse beef protein by using controlled enzymatic hydrolysis process, many factors have to be considered. One of the important factors is the choice of enzymes since different enzymes have different specific activities and optimal working parameters. There were many commercial proteases have been reported to be used for the hydrolysis of beef protein such as alcalase, flavorzyme, bromelain and papain [5 - 7]. However, bromelain is the most preferred to be used in enzymatic hydrolysis as it is proven to give the highest total yield of $\alpha$ amino groups compared to other proteases such as papain and alcalase [6].

Bromelain enzyme is endopeptidase enzyme. It is related to the family of cysteine protease $\mathrm{C} 1$ and has a single chain, glycosylated amino acid cysteine with seven bridges and probably three disulfides [8]. The mechanism of action of cysteine protease to cleave peptide bonds through a double-displacement pathway involving general acidbase formation and hydrolysis of an acyl-thiol intermediate. The initial step in catalytic process involves noncovalent binding of the free enzyme and the substrate to form the complex. This is followed by the acylation of the enzyme with the formation and release of the first product, the amine $\mathrm{R}^{\prime} \mathrm{NH} 2$. In the next deacylation step, the acyl-enzyme reacts with a water molecule to release the second product, with the regeneration of free enzyme [8].

Under standard condition, proteases hydrolysed peptide bond. Bromelain cleave glycol, anayl and leucyl bonds [9]. At pH6, bromelain hydrolysed ethyl ester of L-leuicne, L-arginine, L-glycine, L-phenylalanine, L-tyrosine, L-lysine and L-glycine [10]. In the process of enzymatic hydrolysis, factors such as $\mathrm{pH}$, time, enzyme to substrate level and temperature will influence enzymatic activity. In this context, the main goal of enzymatic hydrolysis of beef was to obtain the maximum leucine content in flank cut of beef. Studying the effect of these hydrolysis parameters on leucine content contribute to the understanding of the protein hydrolysate released. Optimization is one of the methods to find a best alternative from a specified set of alternatives. It is the modern statistically derived experimental designs that are viewed as a way to achieve this purpose.

Response surface methodology (RSM) has been effective in the optimization and monitoring of food processes [11]. Response surface methodology is an empirical modeling technique and was used to estimate the relationship between a set of controllable experimental factors and observed results [12]. A multiple regressions analysis technique that is included in the RSM was performed to determine all the coefficients of linear $\left(\mathrm{X}_{1}, \mathrm{X}_{2}, \mathrm{X}_{3}\right)$, quadratic $\left(X_{1} X_{1}, X_{2} X_{2}, X_{3} X_{3}\right)$ and interaction $\left(X_{1} X_{2}, X_{1} X_{3}, X_{2} X_{3}\right)$ terms to fit a full response surface model for the responses. The goodness of fit of the regression model was defined by determining the coefficient $R^{2}$ and adjusted $\mathrm{R}^{2}$ (multiple correlation coefficient, $\mathrm{R}$ ), which provides a measure of how much variability in the observed response values can be explained by the experimental factors and their interaction [13]. The lack-of-fit test measures the variation of data with regards to the fitted model and is one of the important aspects of a reduced model. If the model does not fit the data well, the lack-of-fit test will be significant. A model should be rejected if the results showed any significance in the lack-of-fit test [14] Patel et al. [15] testified that an insignificant lack-of-fit indicates a good model. The F value for the lack-of-fit can be obtained by dividing the lack-of-fit mean square by its pure error mean square. 
The objective of this study was to determine optimal enzymatic hydrolysis parameter (bromelain concentration, hydrolysis temperature and hydrolysis time) of flank cut of beef to obtain the optimum leucine content by using RSM. Additionally, the degree of hydrolysis and amino acid composition of the optimum beef protein hydrolysate prepared using the optimized hydrolysis conditions were determined.

\section{Chemicals and raw materials}

\section{Materials and Methods}

All chemicals used were purchased from Sigma Chemical Co. (St Louis, Missouri). Peel of pineapple index 2, variety N36 were obtained from Peninsula Plantation Sdn Bhd, Simpang Renggam, Johor, Malaysia and flank cut of beef were obtained from a slaughter house in MZR Livestock (M) Sdn. Bhd, Rantau Panjang, Klang, Selangor, Malaysia.

\section{Optimisation of enzymatic hydrolysis condition}

The optimum enzymatic hydrolysis conditions of flank cut of beef was determined by response surface methodology (MINITAB Software Version 15). The three test variables chosen were bromelain concentration, hydrolysis temperature and hydrolysis time as shown in Table 1 . The experiment was optimized by using threefactors, five levels central composite design (CCD). The central composite design composed of 20 treatments including $2^{3}$ factorial points, six axial points $(\alpha \pm 1.68)$ and six replicates of the central point. The design of experiments and dependent variable values was presented in Table 2.

Table 1. Coded and uncoded variables used in optimisation experiment

\begin{tabular}{lcccccc}
\hline Parameter & Code & $\mathbf{- 1 . 6 8}$ & $\mathbf{- 1}$ & $\mathbf{0}$ & $\mathbf{1}$ & $\mathbf{1 . 6 8}$ \\
\hline Bromelain concentration $(\% \mathrm{w} / \mathrm{w})$ & $\mathrm{X}_{1}$ & 0.5 & 1.0 & 1.5 & 2.0 & 2.5 \\
Hydrolysis temperature $\left({ }^{\circ} \mathrm{C}\right)$ & $\mathrm{X}_{2}$ & 40 & 42.5 & 45 & 47.5 & 50 \\
Hydrolysis time (hours) & $\mathrm{X}_{3}$ & 24 & 30 & 36 & 42 & 48 \\
\hline
\end{tabular}

\section{Enzymatic hydrolysis of beef}

The protein hydrolysate of the beef was produced through enzymatic hydrolysis using bromelain from pineapple peel extract. Clarified pineapple peel extract were purified using cation exchange chromatography to produce purified bromelain. Then the purified bromelain undergo the desalting process whereby this process was carried out by using the diafiltration process. Desalted bromelain was dried using vacuum freeze dryer to produce powdered bromelain. This bromelain powder was used for enzymatic hydrolysis of beef. The enzymatic hydrolysis process was carried out based on Haslaniza et al. [6] method. Two gram (2g) flank cut of beef was placed in $100 \mathrm{~mL}$ conical flask. Then, $50 \mathrm{~mL}$ of distilled water was added. The mixture was then hydrolysed in the oven $\left(95{ }^{\circ} \mathrm{C}\right)$ for 20 minutes followed by cooling to room temperature condition. The $\mathrm{pH}$ of the mixture was adjusted to $\mathrm{pH} 6$ using $4 \mathrm{~N}$ $\mathrm{NaOH}$. Then, enzyme bromelain at different concentrations $(0.5,1.5$ and $2.5 \%(\mathrm{w} / \mathrm{w}))$ were added followed by the addition of $2 \mathrm{~mL}$ of $0.1 \mathrm{M} \mathrm{L}$-Cysteine as a catalyst. The mixture was incubated at $200 \mathrm{rpm}$ in an incubator shaker with temperature $\left(40-50{ }^{\circ} \mathrm{C}\right)$ and time $(24-48$ hours) according to the experimental design as shown in Table 2 . After that, the samples were heated at $95^{\circ} \mathrm{C}$ for $15 \mathrm{~min}$ to deactivate the enzyme. The protein hydrolysate sample was centrifuged at $7800 \mathrm{x}$ g for $15 \mathrm{~min}$ in order to separate any impurities from hydrolysate. The clear supernatants were frozen at $-20{ }^{\circ} \mathrm{C}$ before the freeze drying process.

\section{Determination of amino acid}

The beef protein hydrolysate was hydrolysed using $5 \mathrm{~mL} 6 \mathrm{~N} \mathrm{HCl}$ at $110{ }^{\circ} \mathrm{C}$ for 24 hours. The amino acid content was analysed according to AccQ.Tag Amino acid analysis method [7] using HPLC equipped with a Waters 410 Scanning Flourescence and AccQ Tag column $(3.9 \times 150 \mathrm{~mm})$. AccQ Tag Eluent A (19\% sodium acetate) and AccQ Tag Eluent B (60\% acetonitrile acid) was used as the mobile phase (flow rate $=1 \mathrm{~mL} / \mathrm{min})$. The column temperature was set at $36^{\circ} \mathrm{C}$. The HPLC system was run by concentration gradient in the process of analysing amino acid. 
Siti Roha et al: DETERMINATION OF OPTIMUM CONDITION OF LEUCINE CONTENT IN BEEF

PROTEIN HYDROLYSATE USING RESPONSE SURFACE METHODOLOGY

Table 2. Experimental design by MINITAB Software

\begin{tabular}{|c|c|c|c|c|c|}
\hline \multirow{2}{*}{ Run No } & \multicolumn{3}{|c|}{ Factors } & \multicolumn{2}{|c|}{ Response (Leucine \%) } \\
\hline & $\mathbf{X}_{1}$ & $\mathbf{X}_{2}$ & $\mathbf{X}_{3}$ & Predicted & Experimental \\
\hline 1 & 1 & 42.5 & 30 & 23.618 & 23.587 \\
\hline 2 & 2 & 42.5 & 30 & 25.399 & 25.406 \\
\hline 3 & 1 & 47.5 & 30 & 11.751 & 11.753 \\
\hline 4 & 2 & 47.5 & 30 & 12.046 & 11.997 \\
\hline 5 & 1 & 42.5 & 42 & 12.219 & 12.210 \\
\hline 6 & 2 & 42.5 & 42 & 21.300 & 21.241 \\
\hline 7 & 1 & 47.5 & 42 & 16.030 & 15.966 \\
\hline 8 & 2 & 47.5 & 42 & 23.448 & 23.422 \\
\hline 9 & 0.5 & 45 & 36 & 20.840 & 20.942 \\
\hline 10 & 2.5 & 45 & 36 & 25.452 & 25.579 \\
\hline 11 & 1.5 & 40 & 36 & 26.570 & 26.662 \\
\hline 12 & 1.5 & 50 & 36 & 21.699 & 21.836 \\
\hline 13 & 1.5 & 45 & 24 & 19.762 & 19.833 \\
\hline 14 & 1.5 & 45 & 48 & 19.699 & 19.857 \\
\hline 15 & 1.5 & 45 & 36 & 24.418 & 24.579 \\
\hline 16 & 1.5 & 45 & 36 & 24.682 & 24.579 \\
\hline 17 & 1.5 & 45 & 36 & 24.852 & 24.579 \\
\hline 18 & 1.5 & 45 & 36 & 24.762 & 24.579 \\
\hline 19 & 1.5 & 45 & 36 & 24.550 & 24.579 \\
\hline 20 & 1.5 & 45 & 36 & 24.667 & 24.579 \\
\hline & 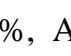 & 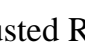 & 9.8 & & \\
\hline
\end{tabular}

\section{Determination of degree hydrolysis and nitrogen content}

The degree of hydrolysis was calculated according to the percentage of trichloroacetic acid (TCA) ratio method as described by Haslaniza et al. [6]. After enzymatic hydrolysis, $20 \mathrm{~mL}$ of beef protein hydrolysate was added into 20 $\mathrm{mL}$ of $20 \%(\mathrm{w} / \mathrm{v})$ TCA to produce $10 \%$ TCA soluble material. The mixture was left to stand for 30 minutes to allow precipitation, and then followed by centrifugation at $7800 \mathrm{x}$ g for 15 minutes. The degree of hydrolysis (DH) was calculated using the following formula equation 1 :

$$
\% \mathrm{DH}=\frac{\text { Soluble N in TCA } 10 \%(\mathrm{w} / \mathrm{v})}{\text { Total } \mathrm{N} \text { in beef }} \times 100
$$

where DH is defined as degree hydrolysis and TCA is defined as trichloroacetic acid.

The nitrogen content in supernatant, powdered beef hydrolysate and flank cut of beef was determined using CHNS elemental analyser. Before the analysis, all the samples were dried for 1 hour in oven at $110^{\circ} \mathrm{C}$.

\section{Statistical analysis}

The results from CCD was assessed using multi linear regression [16] using an equation 2 below:

$$
Y=b_{0}+b_{1} A+b_{2} B+b_{3} C+b_{4} A^{2}+b_{5} B^{2}+b_{6} C^{2}+b_{7} A B+b_{8} A C+b_{9} B C
$$


where $\mathrm{Y}$ represents the predicted response, $b_{0}$ is the value for the fixed response at the central point of the experiment, $b_{1}, b_{2}$ and $b_{3}$ are linear coefficients, $b_{4}, b_{5}$ and $b_{6}$ are quadratic coefficients, and $b_{7}, b_{8}$, and $b_{9}$ are crossproduct or interaction coefficients.

The $\mathrm{R}^{2}$ value and the lack of fit value were determined. After the multifactor analysis of variance and the secondorder model prediction determinations, the optimal enzymatic hydrolysis conditions were obtained by the desirability function approach. The response surface plots were developed to represent a function of two test variables while keeping the other test variable at the optimal value.

For the verification value, the experimental value of response (leucine) was compared to the predicted value of response (leucine). Data were analysed using t-test method using SPSS 20. A significant difference was considered at the level of $\mathrm{p}<0.05$.

\section{Optimization of enzymatic hydrolysis of beef}

\section{Results and Discussion}

A central composite design was performed to study the combined effect of three factors (bromelain concentration, hydrolysis temperature and hydrolysis time) on the response, leucine content (\%). The predicted and experimental results of the 3-factors, 5-levels central composite design was presented in Table 2. The determination of coefficient $\left(\mathrm{R}^{2}\right)$ was $99.94 \%$, which suggested that this quadratic model was appropriately to represent the real relationships among the chosen hydrolysis parameters. The closer the $\mathrm{R}^{2}$ value to one, the better the fitting of the empirical model with the actual data and the better the correlation between experimental and predicted values [16].

The adjusted $\mathrm{R}^{2}$ was a corrected value for $\mathrm{R}^{2}$ after the elimination of unnecessary model terms. If there are many non-significant terms included in the model, the adjusted $R^{2}$ would be smaller than $R^{2}$. In this present study, it is found that the adjusted $R^{2}$ is high and very close to the $R^{2}$. Respective values for adjusted $R^{2}$ and $R^{2}$ were $99.89 \%$ and $99.94 \%$. The high values of adjusted $\mathrm{R}^{2}$ and $\mathrm{R}^{2}$ indicate a high dependence and correlation between the observed values and the predicted values of response.

The effect of experimental variables on the linear, quadratic and interaction terms were tested for adequacy and fitness by analysis of variance (ANOVA). The summary of the results obtained are shown in Table 3 . By using lack-of-fit and correlation coefficient determination $\left(\mathrm{R}^{2}\right)$, the adequacy of the model can be revealed. The significance of the equation parameter for test variables was assessed by $\mathrm{F}$ ratio at a probability (p) of 0.05 . The $\mathrm{F}$ value predicts the quality of the entire model while considering all design factors all at once.

Table 3. ANOVA test for optimisation of leucine content in protein hydrolysate treated with bromelain

\begin{tabular}{llrrrrrl}
\hline Source & DF & Seq SS & Adj SS & Adj MS & \multicolumn{1}{c}{ F } & P & Status \\
\hline Regression & 9 & 431.421 & 431.421 & 47.936 & 1921.790 & 0.000 & Significant \\
Linear & 3 & 112.002 & 5.027 & 1.676 & 67.180 & 0.000 & Significant \\
Square & 3 & 170.656 & 170.656 & 56.885 & 2280.580 & 0.000 & Significant \\
Interaction & 3 & 148.764 & 148.764 & 49.588 & 1988.030 & 0.000 & Significant \\
Residual Error & 10 & 0.249 & 0.249 & 0.025 & & & \\
Lack of fit & 5 & 0.131 & 0.131 & 0.026 & 1.110 & 0.456 & Not significant \\
Pure Error & 5 & 0.118 & 0.118 & 0.024 & & & \\
Total & 19 & 431.670 & & & & & \\
\hline
\end{tabular}

$\mathrm{DF}=$ degree of freedom, Seq SS = sequential sum of square, Adj SS = adjusted sum of square, Adj MS = adjusted mean square, $\mathrm{F}=$ fischer, $\mathrm{P}=$ probability 


\section{Siti Roha et al: DETERMINATION OF OPTIMUM CONDITION OF LEUCINE CONTENT IN BEEF PROTEIN HYDROLYSATE USING RESPONSE SURFACE METHODOLOGY}

The $\mathrm{p}$ value is the probability of the factors having very little or insignificant effect on the response. A larger $\mathrm{F}$ value signifies a better fit of the RSM model to the experimental data [17]. Datta et al. [18] reported that an F value with a low $\mathrm{p}$ value indicates the high significance of the regression model. However, the $\mathrm{p}$ value should be lower than 0.05 for the model to be statistically significant [15]. Based on reports by literatures $[17,18,15]$ the regression model found in this study was highly significant as denoted by the large $\mathrm{F}$ and low $\mathrm{p}$ value of 1921.79 and 0.000 , respectively. From Table 3, it was observed that the quadratic (square) and interaction factors were highly significant compared to linear factors as indicated by the large $F$ values of 2280.58 and 1988.03 with a low $p$ value of 0.000 , each. In this study, the lack of fit model showed a non-significant result ( $p>0.05$ ) with a p value of 0.456 . Thus, the insignificant $\mathrm{p}$ value indicates that the model is good and fits well with the experimental data.

Overall, the analysis of variance suggested that the predicted quadratic model for enzymatic hydrolysis conditions of flank beef cut was statistically valid. The second-order polynomial model equation for the optimisation of leucine in beef hydrolysate treated with bromelain is illustrated as follows:

$$
\begin{aligned}
\mathrm{Y}= & 204.095+12.988 \mathrm{X}_{1}-5.103 \mathrm{X}_{2}-3.124 \mathrm{X}_{3}-5.271 \mathrm{X}_{1}^{2}-0.053 \mathrm{X}_{2}^{2}-0.131 \mathrm{X}_{3}^{2}-0.315 \mathrm{X}_{1} \mathrm{X}^{2}+0.601 \mathrm{X}_{1} \mathrm{X}^{3} \\
& +0.260 \mathrm{X}_{2} \mathrm{X}^{3}
\end{aligned}
$$

where $\mathrm{X}_{1}=$ concentration of bromelain, $\mathrm{X}_{2}=$ hydrolysis temperature, $\mathrm{X}_{3}=$ hydrolysis time .

Based on Table 4, it was found that the optimum conditions for the target goal with a bromelain concentration of $1.38 \%(\% \mathrm{w} / \mathrm{w})$, hydrolysis temperature of $42.5{ }^{\circ} \mathrm{C}$ and hydrolysis time of 31.59 hours as well as for the minimum goal with a bromelain concentration of $1 \%(\% \mathrm{w} / \mathrm{w})$, hydrolysis temperature of $47.5{ }^{\circ} \mathrm{C}$ and hydrolysis time of 30 hours were feasible to be carried out. Meanwhile, the optimum condition for the maximum goal with a bromelain concentration of $1.93 \%(\% \mathrm{w} / \mathrm{w})$, hydrolysis temperature of $42.5{ }^{\circ} \mathrm{C}$ and hydrolysis time of 38.48 hours was not feasible to be carried out. This is in accordance with the optimum conditions for the target and minimum goals being located in the white area or in the feasible region based on the overlaid contour plots obtained. Meanwhile, the optimum condition for the maximum goal is located in the grey area or non-feasible region. However, the optimum condition for the target goal was chosen because the response value was higher compared to the optimum condition for the minimum goal.

\section{Condition for optimum response}

The optimum conditions of enzymatic hydrolysis of flank cut of beef were $1.38 \%(\% \mathrm{w} / \mathrm{w})$ for bromelain concentration, $42.5^{\circ} \mathrm{C}$ for hydrolysis temperature and 31.59 hours for hydrolysis time.

The Dimension (2D) contour and (3D) surface plots for leucine content in protein hydrolysate treated with bromelain at a feasible optimum condition are shown in Figures 1 and 2, respectively. The shape of the contour plot (circular or elliptical) indicates whether the mutual interaction between test variables is significant or not. A circular contour plot indicates that the interaction between related test variables is negligible. In contrast, an elliptical contour plot indicates that the interaction between related test variables is significant [19]. In this study, results revealed that the contour plot was elliptical, indicating that there is a significant interaction effect between bromelain concentration, hydrolysis temperature and hydrolysis time on the leucine content in protein hydrolysate.

Validation for the optimum condition of leucine content in protein hydrolysate treated with bromelain was performed and the results are $26.25 \%$ and $26.57 \%$ for validation and predicted response, respectively. The suitability of the model equation for predicting the optimum response value was evaluated for the optimum condition of leucine content under conditions where the bromelain concentration is $1.38 \%$, hydrolysis temperature is $42.5^{\circ} \mathrm{C}$ and hydrolysis time is 31.59 hours. Optimisation using actual experimental values was tested using the $\mathrm{t}$-test (SPSS). There was no significant difference $(\mathrm{p}>0.05)$ between predicted and verified values. Thus, indicating that the model was significant and can be used to predict the optimisation of leucine content in protein hydrolysate. 
Table 4. Comparison values of target and predicted responses for different optimum conditions and experiment feasibilities

\begin{tabular}{|c|c|c|c|c|c|c|c|c|c|}
\hline \multirow[t]{2}{*}{ Goal } & & \multirow[t]{2}{*}{ Lower } & \multirow[t]{2}{*}{ Target } & \multirow[t]{2}{*}{ Upper } & \multicolumn{3}{|c|}{$\begin{array}{l}\text { Optimum } \\
\text { condition }\end{array}$} & \multirow{2}{*}{$\begin{array}{c}\text { Predicted } \\
\text { Response } \\
\text { (FITS) }\end{array}$} & \multirow[t]{2}{*}{ F/NF } \\
\hline & & & & & $\mathbf{X}_{1}$ & $\mathbf{X}_{2}$ & $\mathbf{X}_{3}$ & & \\
\hline \multirow{2}{*}{ Target } & Leucine (\%) & 11.751 & 26.569 & 26.570 & \multirow[t]{2}{*}{1.38} & \multirow[t]{2}{*}{42.5} & \multirow[t]{2}{*}{31.59} & \multirow[t]{2}{*}{26.5699} & \multirow[t]{2}{*}{$\mathrm{F}$} \\
\hline & FITS 1 & 11.753 & 26.661 & 26.662 & & & & & \\
\hline \multirow{2}{*}{ Maximum } & Leucine $(\%)$ & 11.751 & 26.570 & 26.570 & \multirow[t]{2}{*}{1.93} & \multirow[t]{2}{*}{42.5} & \multirow[t]{2}{*}{38.48} & \multirow[t]{2}{*}{28.3081} & \multirow[t]{2}{*}{$\mathrm{NF}$} \\
\hline & FITS 1 & 11.753 & 26.662 & 26.662 & & & & & \\
\hline \multirow{2}{*}{ Minimum } & Leucine (\%) & 11.751 & 11.751 & 26.570 & \multirow[t]{2}{*}{1.00} & \multirow[t]{2}{*}{47.5} & \multirow[t]{2}{*}{30.00} & \multirow[t]{2}{*}{11.7528} & \multirow[t]{2}{*}{$\mathrm{F}$} \\
\hline & FITS 1 & 11.753 & 11.753 & 26.662 & & & & & \\
\hline
\end{tabular}

$\mathrm{X}_{1}=$ bromelain concentration $(\% \mathrm{w} / \mathrm{w}), \mathrm{X}_{2}=$ hydrolysis temperature $\left({ }^{\circ} \mathrm{C}\right), \mathrm{X}_{3}=$ hydrolysis time (hours), FITS $=$ predicted response $(\%), \mathrm{F}=$ feasible, $\mathrm{NF}=$ not feasible

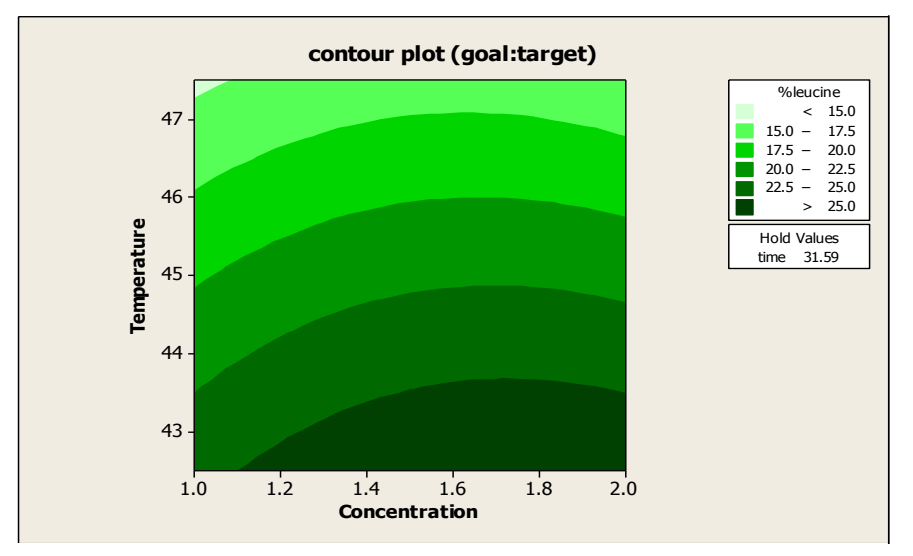

Figure 1. Contour plot of leucine in protein hydrolysate treated with bromelain at a feasible optimum condition, with a bromelain concentration of $1.38 \%$, hydrolysis temperature of $42.5{ }^{\circ} \mathrm{C}$ and hydrolysis time of 31.59 hours (holding value: hydrolysis time at 31.59 hours)

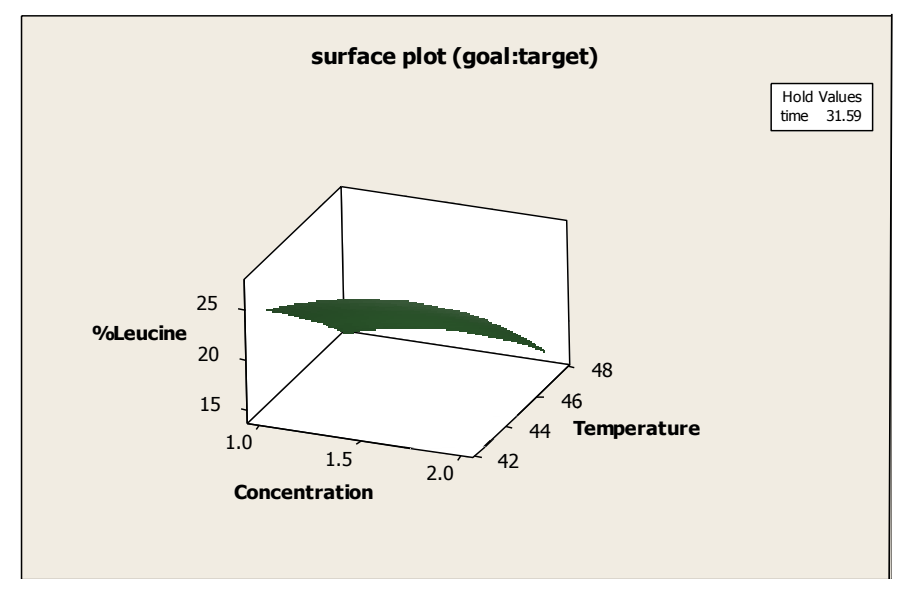

Figure 2. Surface plot of leucine in protein hydrolysate treated with bromelain at a feasible optimum condition with a bromelain concentration of $1.38 \%$, hydrolysis temperature of $42.5^{\circ} \mathrm{C}$ and hydrolysis time of 31.59 hours (holding value: hydrolysis time at 31.59 hours ) 


\section{Leucine content, nitrogen content and degree hydrolysis}

It was found that leucine content was significantly high in the treated beef compared to untreated flank beef cut. The difference is due to the characteristics of bromelain which contains protease and is able to release more amino acid in treated beef than in untreated beef [20]. Stein et al. [21] carried out an enzymatic hydrolysis of Atlantic cod viscera using different types of enzymes (actinidin, alcalase, bromelain, neutrase, papain and protamex). They found that bromelain gave the highest total yield of the alpha amino group, signifying that the highest amount of peptide bonds could be broken in the reaction.

Table 5. Degree of hydrolysis, comparison of leucine and nitrogen content in flank cuts and beef hydrolysate before and after treatment

\begin{tabular}{lll}
\hline Analysis & Flank cut of beef & Flank cut of beef hydrolysate \\
\hline Leucine & $2.277 \pm 0.003^{\mathrm{b}}$ & $5.453 \pm 0.003^{\mathrm{a}}$ \\
Nitrogen & $13.22 \%^{\mathrm{b}}$ & $15.16 \%^{\mathrm{a}}$ \\
Degree of hydrolysis & - & $61.73 \%$ \\
\hline
\end{tabular}

Means within each row was significantly different at $\mathrm{p}<0.05$.

It was found that the nitrogen content in the flank cuts and beef hydrolysate were $13.22 \%$ and $15.16 \%$, respectively (Table 5). These results corresponds to previous findings by Haslaniza et al. [6] who discovered that cockle meat that went through an enzymatic hydrolysis using a bromelain concentration of $1.5 \%$ had a higher nitrogen content compared to raw cockle meat. The degree of hydrolysis $(\mathrm{DH})$ was determined for the optimum condition of protein hydrolysate. DH refers to the percentage of enzymatically hydrolysed peptide bonds compared to the original peptide bonds in raw materials, representing a number of peptide bonds being degraded during the reaction. DH can be simplified as the percentage of cleaved peptide bonds. In this present study, DH was calculated according to the percentage of trichloroacetic acid ratio. High DH indicates a high level of protein hydrolysed into smaller peptides and free amino acids [7]. Based on this study, it was found that the percentage of the degree of hydrolysis (DH) was $61.73 \%$, indicating a high DH of beef protein hydrolysis using the bromelain enzyme.

\section{Conclusion}

The leucine content of protein hydrolysate from flank cut of beef was significantly affected by the hydrolysis conditions including enzyme concentration, temperature and time. According to the model, the optimum hydrolysis parameters were $1.38 \%(\mathrm{w} / \mathrm{w})$ of bromelain concentration, hydrolysis temperature of $42.5{ }^{\circ} \mathrm{C}$ and hydrolysis time of 31.59 hours. Based on the optimum hydrolysis condition, the protein hydrolysate was obtained at higher amount of leucine and degree of hydrolysis.

\section{Acknowledgement}

Special thanks to Ministry of Higher Education, Malaysia for funding this project under Fundamental Research Grant Scheme [600-RMI/ST/FRGS/Fst(32/2010)] and also Peninsula Plantation Sdn Bhd, Simpang Renggam, Johor, Malaysia for supplying pineapple for this project.

\section{References}

1. Cordts, A., Nitzko, S. and Spiller, A. (2014). Consumer response to negative information on meat consumption in Germany. International Food and Agribusiness Management Review, 17: 83 - 106.

2. Scollan, N., Hocquette, J. F., Nuernberg, K. and Dannenberger, D. (2006). Innovation in beef production systems that enhance the nutritional and health value of beef lipids and their relationship with meat quality. Meat Science, 70: 17 - 33.

3. Hollo, G., Nuernberg, K. and Hollo, I. (2007). Effect of feeding on the composition of longissmus muscle of hungarian grey and the holsteh friesian bulls. Arch Tierz Dummersturf, 50(6): 575 - 586. 
4. Bjoern, A. M., Schrader, H. and Ritter, D. R. (2010). Selective amino acid deficiency in patients with impaired glucose tolerance and type 2 diabetes. Regulatory Peptide, 160: 75 - 80 .

5. Murna, M., Novi, S. and Fahrizal, Z. (2012). Production of protein hydrolysates from fish byproduct prepared by enzymatic hydrolysis. International Journal of the Bioflux Society, 5(1): 36 - 39.

6. Haslaniza, H., Maskat, M. Y., Wan Aida, W. M. and Mamot, S. (2010). The effects of enzyme concentration, temperature and incubation time on nitrogen content and degree of hydrolysis of protein precipitate from cockle (Anadara granosa) meat wash water. International Food Research Journal, 17: 147 - 152.

7. Apiwatanapiwat, W., Vaithanomsat, P., Somkliang, P. and Malapant, T. (2009). Optimization of protein hydrolysate production process from Jatropha curcas cake. International Journal of Chemical and Biological Engineering 2(3): $161-164$.

8. Fernandes, H. P., Cesar, C. L. and Barjas-Castro, M. D. L. (2011). Electrical properties of the red blood cell membrane and immunohematological investigation. Revista Brasileira de Hematologia e Hemoterapia, 33(4): $297-301$.

9. Bhattacharyya, B. K. (2008). Bromelain: An overview. Natural Product Radiance, 4: 359 - 363.

10. Boyer, P. D. (1997). The enzymes: Hydrolysis other C-N bonds, phosphate ester. The enzymes (3 ed.): Academic press.

11. Wangtueai, S. and Noomhorm, A. (2009). Processing optimization and characterization of gelatin from lizardfish (Saurida spp.) scales. LWT-Food Science and Technology, 42: 825 - 834.

12. Gomes, N., Teixeira, J. A. and Belo, I. (2011). Empirical modelling as an experimental approach to optimize lactone production. Catalysis Science \& Technology, 1: $86-92$.

13. Sudamalla, P., Saravanan, P. and Matheswaran, M. (2012). Optimisation of operating parameters using response surface methodology for adsorption of crystal violet by activated carbon prepared from mango kernel. Sustainable Environment Research, 22: 1 - 7.

14. Siti Nadiah, S., Noorlaila, A., Mohd Zahid, A., Norziah, M. H. and Normah, I. (2013). Optimization of hydrocolloids and maltodextrin addition on roselle-based fruit leather using two-level full factorial design. International Journal of Bioscience, Biochemistry and Bioinformatics, 3(4): 387 - 391.

15. Patel, S., Kothari, D. and Goyal, A. (2011). Enhancement of dextransucrase activity of Pediococcus pentosaceus SPAm1 by response surface methodology. Indian Journal of Biotechnology, 10: 346 - 351.

16. Zaibunnisa, A. H., Norashikin, S., Mamot, S. and Osman, H. (2009). An experimental design approach for the extraction of volatile compounds from turmeric leaves (Curcuma domestica) using pressurized liquid extraction (PLE). LWT Food Science Technology, 42: 233 - 238.

17. Panwal, J. H., Viruthagiri, T. and Baskar, G. (2011). Statistical modeling and optimization of enzymatic milk fat splitting by soybean lecithin using response surface methodology. International Journal of Nutrition and Metabolism, 3: 50-57.

18. Datta, D. and Kumar, S. (2012). Modeling and optimisation of recovery process of glycolic acid using reactive extraction. International Journal of Chemical Engineering and Applications, 3: 141 - 146.

19. Mannan, S., Fakhru'l-Razi, A. and Md Zahangir, A. (2007). Optimization of process parameters for the bioconversion of activated sludge by Penicillium corylophilum, using response surface methodology. Journal of Environmental Sciences, 19: 23 - 28.

20. Harckova, M., Rusnakova, M. and Zemonovic, J. (2002). Enzymatic hydrolysis of defatted soy flour by three different proetease and their effect on the functional properties of resulting protein hydrolysates. Czech Journal Food Science, 20(1): $7-14$.

21. Stein, I. A., Svein, J. H., Vincent, G. H., and Eijsinka. (2005). Enzymatic hydrolysis of Atlantic cod (Gadus morhua L.) viscera. Process Biochemistry, 40: 1957 - 1966. 